\title{
Result Based Manajemen Sistem untuk Monitoring dan Evaluasi Kegiatan Bimbingan Dasar Keislaman
}

\author{
Okfalisa*, Harris Simaremare, Rahmad Abdillah, Nina Fadilah Najwa \\ Universitas Islam Negeri Sultan Syarif Kasim Riau
}

Naskah Diterima : 14 Februari 2019; Diterima Publikasi : 9 Mei 2019

DOI : 10.21456/vol9iss1pp77-85

\begin{abstract}
The development of a University based on Islamic adoption is not easy. The Islamic values in the integrated curriculum should be reflected in governance, teaching lifestyle, and society dedication. One of activity as the readmission was introduced by Islamic Basic Mentoring Program. This function became University program that periodically conducted during the working semester since 2010. Unfortunately, the quintessential of this activity could not be achieved thus provoked the emergence of stakeholder dissatisfaction. This research developed a Result Based Model for monitoring and evaluating the execution program. The model investigated 7 constructs with 32 indicators that had been statistically tested by Confirmatory Factor Analysis. The analysis found the significant level and the corelation amongst indicators and constructs. The mechanism of model was interpreted through the construction of prototype system namely Result Based Management Information System. This prototype was established by applying Object Oriented Analysis thus successfully provided a good result in Black box and User Acceptance Test (UAT). As a case study, Islamic Basic Mentoring Program in Faculty Science and Technology was monitored and evaluated by this prototype application. The system was successfully identified the emergence of obstacles by tracking day to day activity. Performance information was graphically presented to assist management level in making decision and fast corrective action. The discussion forum was developed as sharing information platform amongst the faculty management, head program, program committee, program supervisors, program assistants, and the participants. Thus, the monitoring and evaluating program was transparency transformed across management level in that Faculty.
\end{abstract}

Keywords: Islamic Integration; Result Based Management Information System; Performance Measurement

\begin{abstract}
Abstrak
Pembangunan sebuah Universitas berbasis islam tidaklah mudah. Nilai keislaman dalam wujud kurikulum terintegrasi harus tercermin dalam tata kelola, gaya hidup pendidikan pengajaran dan pengabdian masyarakat. Salah satu kegiatan yang sesuai dengan misi tersebut adalah program mentoring dasar keislaman. Kegiatan ini menjadi program Universitas yang dilakukan secara berkala di semester aktif sejak tahun 2010. Namun, capaian ideal dari kegiatan ini tidak dapat diraih secara maksimal sehingga memicu munculnya ketidakpuasan pemangku kepentingan. Penelitian ini membangun sebuah model berbasis konsep Result Based untuk memonitor dan mengevaluasi pelaksanaan kegiatan mentoring. Model ini mengidentifikasi 7 konstrak dengan 32 indikator yang telah teruji secara statistika dengan Confirmatory Factor Analysis. Hasil analisis menemukan tingkat kepentingan dan korelasi antara indikator dan konstrak. Mekanisme model digambarkan melalui pembangunan prototype sistem yaitu Result Based Management Information System. Pembangunan prototipe ini dilakukan dengan menggunakan analisis Object Oriented yang memberikan hasil yang memuaskan pada pengujian Black Box dan User Acceptance Test (UAT). Sebagai studi kasus, Program mentoring dasar keislaman di Fakultas Sains dan Tenologi telah di monitor dan di evaluasi dengan menggunakan aplikasi prototipe ini. Sistem berhasil mengidentifikasi hambatan yang terjadi melalui pelacakan aktivitas sehari-hari. Informasi kinerja disajikan secara grafis untuk membantu tingkat manajemen dalam mengambil keputusan dan tindakan korektif yang cepat. Forum diskusi dikembangkan sebagai platform berbagi informasi antara manajemen fakultas, ketua program, pengelola program, pembimbing program, pementor, dan para peserta. Dengan demikian, pemantauan dan evaluasi program ditransformasikan secara transparan pada lintas tingkat manajemen di Fakultas tersebut.
\end{abstract}

Keywords: Integrasi Keislaman; Result Based Management Information System; Pengukuran Kinerja

\section{Pendahuluan}

Sebagai Universitas yang berbasis keislaman, Universitas Islam Negeri (UIN) seluruh Indonesia mendefinisikan nilai yang menjadi pembeda antara UIN dan Universitas yang telah ada sebelumnya. Salah satunya adalah dengan menonjolkan kurikulum Integrasi keislaman, dimana program studi apapun

*) Penulis korespondensi: okfalisa@gmail.com 
harus menyandarkan nilai-nilai dasarnya pada nilainilai keislaman. Dalam menerjemahkan perpaduan Sains dan Islam ini, setiap UIN di seluruh Indonesia memiliki pandangan tersendiri pada level implementasinya. Khususnya UIN SUSKA Riau, mendeklarasikan bahwa yang menjadi keunggulan utamanya adalah melakukan integrasi Sains, Teknologi dan Seni dengan Islam. Nilai dasar ini dimanifestasikan ke dalam bentuk yang disebut sebagai Kurikulum Integrasi Sains, teknologi dan seni dengan Islam.

Nilai keislaman harus tercermin ke dalam tata kelola dan gaya hidup pendidikan pengajaran dan pengabdian masyarakat yang dilaksanakan oleh Universitas. Sebagai contoh, penelitian yang dilakukan berlandaskan pada Al-quran maupun literatur keislaman. Penanaman nilai keislaman kedalam setiap individu civitas akademika baik dosen, karyawan, dan terutama mahasiswa adalah hal yang sangat penting. Pembentukan dan penanaman nilai akhlaq islami menjadi sasaran dari Kurikulum Integrasi yang telah dirancang. Tujuan akhirnya adalah profil mahasiswa yang dihasilkan oleh institusi UIN SUSKA Riau.

Salah satu kegiatan yang terdapat pada kurikulum integrasi khususnya untuk program studi yang bersifat non-keagamaan adalah kegiatan yang disebut dengan "Mentoring Dasar Keislaman". Kegiatan tersebut bertujuan untuk menguatkan nilai-nilai dasar keislaman yang materinya mencakup Al-Quran, Akidah Islamiah, Praktek Ibadah, Pembinaan Akhlaq Islami dan melatih kemampuan untuk dapat memberikan pemahaman agama Islam kepada masyarakat. Pelaksanaan mentoring di UIN SUSKA Riau untuk fakultas umum telah dilakukan pada Fakultas Sains dan Teknologi, Fakultas Pertanian dan peternakam, dan Fakultas Psikologi.

Saat ini hampir semua perguruan tinggi menerapkan penggunaan teknologi dan sistem informasi sebagai pendukung kegiatan operasional dalam kegiatan usaha instansi (Solechan \& Prasandy, 2016). Penggunaan sistem informasi manajemen (MIS) pada perguruan tinggi sebagai integrasi pengguna dan sistem komputerisasi untuk input dan output data, memproses informasi, dan mendukung aktivitas (El-ebiary, Mahmoud, \& Alzubi, 2016). MIS harus mampu meningkatkan komunikasi dalam perguruan tinggi dengan seluruh stakeholder yang didokumentasikan dan dilakukan maintenance database menjadi lebih efisien (Elebiary et al., 2016).

Komunikasi pada menejemen perguruan tinggi sangat penting, terutama dalam mengakomodir transformasi pengetahuan, target dan capaian dari setiap level. Hal ini tentunya akan meningkatkan efektifitas dan efisiensi bisnis organisasi (Okfalisa \& Dayub, 2015). Kinerja organisasi sebagai hasil dari proses manajemen pengetahuan akan berbeda dengan kinerja organisasi yang mengabaikan pengelolaan intellectual capital (Saide et al., 2017).

Result Based Management (RBM) merupakan alat pengukur performansi yang membantu pihak pembuat policy dan keputusan dalam menyelusuri perkembangan dan pengaruh dari program, kegiatan ataupun policy yang dibentuk (Kusek dan Rist, 2004). Evaluasi performansi terhadap organisasi sangat penting dilakukan untuk memahami bagaimana manajemen berkontribusi terhadap tujuan dan strategi organisasi (Solechan \& Prasandy, 2016).

Penggunaan RBM dapat membantu meningkatkan performansi organisasi melalui proses pembelajaran yang penuh dengan tanggung jawab (Ortiz Fontaine, Kuyama, Munch, \& Tang, 2004), (United Nation Development Group, 2011) dalam (MacKenzie, 2008; Meier, 2003). Penelitian lainnya menggambarkan bagaimana pengalaman dari berbagai organisasi yang telah mengidentifikasikan efektivitas peranan dan manfaat RBM (Mayne, 2007). Penggunaan RBM dapat menghasilkan hasil dan temuan yang lebih baik dibandingkan dengan best practices yang ada saat ini pada sektor publik (Arif, Jubair, \& Ahsan, 2017). Hasil positif RBM seperti dalam tujuan program, kualitas laporan tahunan yang tinggi, dan pembuktian dampak dari program yang dijalankan(Mckernan, Kennedy, \& Aldred, 2016).

Penelitian ini mengimplementasikan konsep RBM dalam proses evaluasi (pengukuran performansi), kemudian merancang aplikasi MIS sebagai tools untuk melakukan proses evaluasi. Pengukuran difokuskan pada monitoring dan evaluasi yang dilakukan pada kegiatan mentoring dasar keislaman dilakukan dengan merujuk kepada pencapaian Output, Outcome dan Impact dari kegiatan tersebut terhadap seluruh stakeholder. Penelitian dilakukan untuk mengevaluasi perubahan sikap mahasiswa, khususnya mahasiswa Fakultas Sains dan Teknologi yang mengikuti program mentoring dasar keislaman. Mahasiswa yang terlibat adalah mahasiswa semester 1 dan semester 2 .

Penelitian ini juga mendefinisikan faktor kunci keberhasilan program mentoring, kemudian diimplementasikan dalam aplikasi berbasis teknologi Informasi (MIS). Sistem akan mengevaluasi berdasarkan parameter keberhasilan yang ditetapkan. Selanjutnya, akan dapat dilihat sejauh mana pengaruh kegiatan mentoring terhadap pencapaian tujuan kurikulum integrasi yaitu melahirkan sarjana muslim yang kokoh akidahnya, mantap ibadahnya, mulia akhlaqnya (Azmi, 2006), luas dan dalam ilmu dan wawasannya (Zuhairini, 2000), mapan keterampilan hidupnya (Sirait, 2008), tinggi etos kerjanya (Irham, 2012), dan memiliki kebugaran jasmani untuk diabdikan kepada bangsa negara dan umat (Mutohir \& Maksum, 2007). 


\section{Kerangka Teoritis}

\subsection{Result Based Management Information System dalam Monitoring dan Evaluasi}

Result Based Management (RBM) adalah suatu strategi menejemen yang melibatkan seluruh stakeholder baik secara langsung ataupun tidak dalam upaya pencapaian suatu "hasil" (meliputi output, outcome dan goal) (Handbook, 2010). RBM dapat dijadikan sebagai tools untuk memonitor dan self assessment dalam pencapaian suatu hasil, baik dalam bentuk laporan maupun performansi. RBM sebagai suatu daur hidup terdiri dari 3 proses utama, yaitu Planning, Monitoring dan Evaluasi.

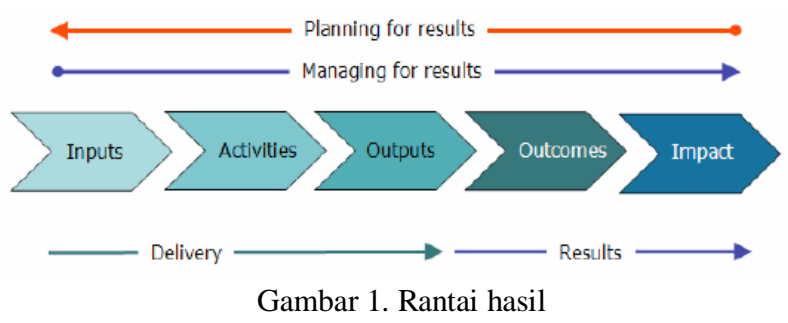

\subsection{Formulasi Hasi/Output (Result)}

Hasil dapat dikatakan sebagai perubahan terukur dari suatu keadaan sebab akibat. Perubahan tersebut dapat berupa intended or unintended (perubahan yang diinginkan ataupun tidak), positif dan/atau negatif. Hal ini berkaitan dengan output, outcome dan impact yang dihasilkan.

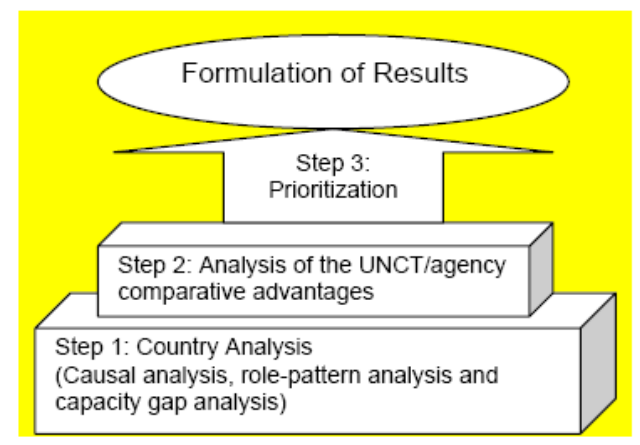

Gambar 2. Tahapan formulasi "Hasil"

\subsection{Merancang Sistem Monitoring dan Evaluasi}

Langkah perancangan sistem monitoring dan evaluasi berbasiskan RBM yaitu (Gambar 3) melakukan penilaian kesiapan, membuat kesepakatan terhadap outcome yang hendak dicapai, memilih indikator-indikator kunci untuk memonitor outcome, mengukur performansi berdasarkan indikator kunci, membuat rencana perbaikkan dengan memilih target yang akan dihasilkan, melakukan monitoring terhadap hasil, melakukan evaluasi, membuat laporan temuan, menggunakan temuan, keberlanjutan sistem evaluasi dan monitoring terhadap organisasi (Kusek \& Rist, 2004).

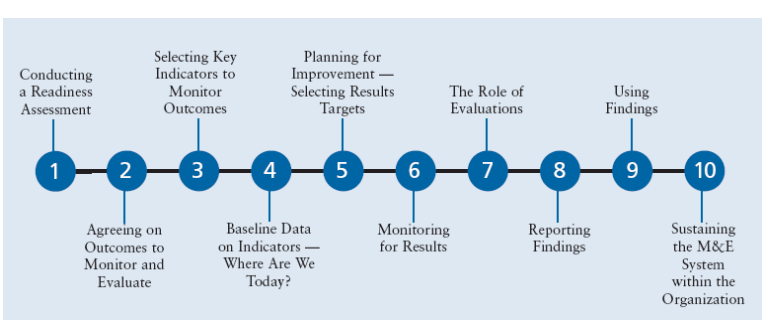

Gambar 3. Langkah perancangan sistem monitoring dan evaluasi berbasiskan RBM

\subsection{Management Information System (MIS)}

Konsep dasar MIS adalah berupa pengelolaan informasi dan data dari sebuah organisasi dan menampilkannya dalam bentuk laporan tertentu. MIS dapat juga berbentuk Sistem Informasi, Sistem Informasi dan Pengambilan Keputusan, Sistem Informasi berbasis Komputer. Manfaat dari penggunaan MIS adalah meningkatkan efektivitas organisasi, mematikan efisiensi dan efektivitas penggunaan sumber daya, proaktif dalam mempromosikan manajemen bisnis, dan membangun sebuah pembelajaran bagi organisasi (a learning organisation) (El-ebiary et al., 2016).

\subsection{Penelitian Terdahulu}

Konsep result based diterapkan pada penelitian yang dilakukan oleh (Ortiz Fontaine et al., 2004), (United Nation Development Group, 2011) yang membuat suatu kesimpulan bahwa RBM dapat membantu meningkatkan performansi organisasi melalui proses pembelajaran yang penuh dengan tanggung jawab (MacKenzie, 2008; Meier, 2003). Penelitian yang dilakukan oleh (Mayne, 2007) mengidentifikasikan efektivitas peranan dan manfaat RBM melalui 6 prinsip utama yaitu meningkatkan kepemimpinan menejer senior dalam RBM, mempromosi dan mendukung budaya hasil, membangun framework hasil dengan kepemilikan yang tinggi dari semua level, mengukur tingkat sensibilitas dan membangun user friendly RBM Information System, menggunakan informasi hasil untuk pembelajaran dan menajemen selain sebagai laporan dan pertanggung jawaban, membangun RBM yang mampu beradaptasi sesuai dengan hasil review dan perubahan.

Penggunaan RBM dan KPI telah banyak digunakan pada manajemen proyek dan terbukti menghasilkan hasil yang lebih baik dibandingkan best practice yang ada pada saat ini (Arif et al., 2017). Penggunaan RBM dalam sektor non-profit memberikan hasil positif dalam pencapaian tujuan program, kualitas pelaporan laporan tahunan yang tinggi, dan lebih banyak memberikan bukti pada dampak program yang dijalankan dalam organisasi (Mckernan et al., 2016).

Penelitian yang dilakukan oleh (El-ebiary et al., 2016), mengkaji terkait efektivitas, manfaat dan tantangan dari penerapan MIS pada perguruan tinggi. Dengan adanya MIS, produktifitas dan performansi 
perguruan tinggi dapat meningkat. Kesalahan administrasi dan proses pengambilan keputusan yang sulit juga dapat diminimalisir. Sehingga, adanya keterkaitan positif antara penerapan MIS dengan efektivitas perguruan tinggi.

Perbedaan penelitian saat ini dengan penelitian yang terdahulu lainnya adalah penggunaan RBM dan pendefinisian KPI yang diimplementasikan ke dalam sebuah sistem manajemen informasi (MIS).

\section{Metode}

\subsection{Identifikasi Permasalahan}

Tahap ini dilalui dengan tinjauan pustaka dan wawancara. Wawancara dilakukan untuk mendapatkan pandangan yang lebih dalam mengenai proses pelaksanaan kegiatan mentoring dasar keislaman (Creswell, 2003). Secara umum, kedua aktivitas tersebut akan menerapkan analisa isi/konten secara kuantitatif (Stemler, 2001). Hal ini dilakukan dengan menemukan kata kunci dan pemahaman yang sejenis dengan konteks penelitian. Hasil interview ditranskripsikan dengan menggunakan tabel kesimpulan guna memperoleh analisa lebih lanjut (Matthew \& Micheal, 1994).

\subsection{Pembangunan Instrumen}

Komponen yang menjadi input, aktivitas, output, outcome dan impact sebagai instrumen utama dijelaskan sesuai dengan tabel acuan dalam RBM (Speckley, 2009).

Pembangunan Tabel Acuan RBM. Tabel Acuan RBM dibangun guna mengatur proses monitoring proyek atau kegiatan yang dilaksanakan mulai dari perencanaan proyek hingga tahapan evaluasi akhir. Tabel ini berisikan evaluasi pelaksanaan kegiatan secara periodik dan keterlibatan stakeholder baik secara perorangan maupun organisasi dalam kegiatan tersebut.

Analisa Perbandingan dan Penilaian Proyek. Analisa yang dilakukan adalah memonitor derajat kepentingan proyek yang memiliki impact terhadap personal maupun organisasi. Analisis juga dilakukan untuk mengidentifikasi stakeholder potensial tendensi dan sejauh mana keterlibatan mereka dalam proyek kegiatan. Penilaian Kapasitas Institusional dapat dijabarkan dalam analisis ini berbentuk Strenght Weaknessess Opportunities Threats (SWOT) Analisis.

Indikator dan Konstrak. Berdasarkan survei awal melalui wawancara terhadap beberapa stakeholders yang terlibat, diperoleh beberapa kesimpulan yang dikaitkan dengan pembentukan indikator atau konstrak yaitu: Kokoh akidahnya, Mantap ibadahnya, Mulia akhlaqnya, Luas dan dalam ilmu dan wawasannya, Mapan keterampilan hidupnya, Tinggi etos kerjanya, serta Bugar jasmaninya.

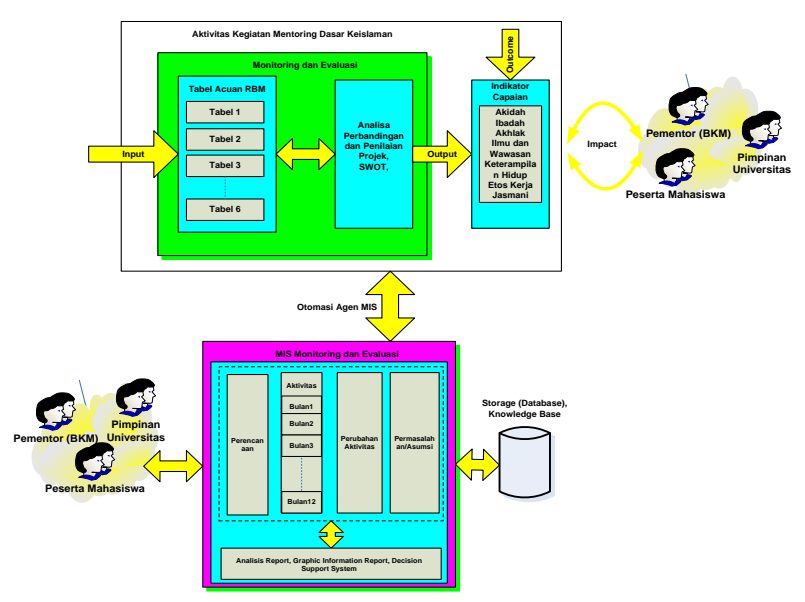

Gambar 4. Operasional Framework Resulted Based Manajemen Sistem

Operasional framework dalam pembangunan model dijelaskan di Gambar 4. Proses Input dilakukan dengan mencatat keseluruhan aktivitas, perubahan maupun hambatan dan tantangan, keterlibatan stakeholders dalam semua kegiatan, Output dan Outcome yang diharapkan serta analisis Impact aktivitas kegiatan tersebut terhadap seluruh stakeholders. Mekanisme konsep RBM di automasikan dalam bentuk pembangunan rancangan MIS yang menata dan mengelola seluruh aktivitas serta informasi kegiatan. Dari gambar tersebut juga dapat dilihat bagaimana keterlibatan seluruh stakholders dalam proses monitoring kegiatan.

Pembangunan Rubrik. Rubrik digunakan sebagai acuan dan standar dalam pembuatan salah satu instrumen penelitian yaitu kuisioner. Pengukuran dilakukan berdasarkan performansi capaian dari indikator dan konstrak yang telah dibangun. Terdapat 3 kuisioner yang digunakan. Kuisioner-1 untuk memvalidasi indikator dan konstrak yang telah ditemukan secara teoritikal yang disebarkan kepada pengelola dan pihak pimpinan. Kuisioner ke-2 untuk mengukur performansi capaian kesuksesan pelaksanaan kegiatan mentoring dasar keislaman berdasarkan outcome yang diinginkan yang diperuntukkan kepada peserta dan pementor dan Kuisioner-3 sebagai alat ukur performansi pementor dan dosen pendamping/pembimbing yang diisi oleh peserta dan pementor.

\subsection{Pembangunan dan Validasi Indikator}

Tahap ini menjelaskan proses pembangunan indikator yang diperoleh berdasarkan hasil analisa instrumen pada tahap sebelumnya. Guna menstandarisasikan pembangunan indikator ini, maka rubrik (Johnston, Tomlinson, \& Susan, 2007) yang menggambarkan kinerja masing-masing indikator akan dibangun. Aktivitas ini meliputi proses survei dan analisis data.

Survei dilakukan di beberapa fakultas di UIN SUSKA Riau, seperti Fakultas Peternakan, Fakultas 
Ekonomi, Fakultas Tarbiyah dan Fakultas Pendidikan Agama Islam. Tujuan survei ini adalah untuk mencari kesepakatan responden berkaitan dengan indikator-indikator yang diajukan dalam penelitian ini. Penyebaran kuisioner dilakukan secara langsung maupun e-mail kepada para responden. Kuisioner dibuat dalam bentuk format pertanyaan closed-ended dengan menggunakan rentang skala 5 (George, 2006).

Analisis data menggunakan Statistical Package for the Social Sciences (SPSS) windows 10. Untuk mencari nilai covariance dari keterhubungan indikator dan konstrak, maka Confirmatory Factor Analysis (CFA) digunakan untuk mengkonfirmasi struktur dan mengevaluasi pengelompokkan dari indikator dan konstrak yang ada (Coakes \& Sheridan, 2003). Hasil tahap ini akan diperoleh indikatorindikator baru yang sudah teruji validitasnya.

\subsection{Rancang Bangun Prototipe MIS Monitoring dan Evaluasi}

Hasil dari monitoring dan evaluasi proses dengan menggunakan metode RBM akan diimplementasikan dalam bentuk pembangunan software. Software ini berfungsi sebagai agen yang melakukan proses monitoring dan evaluasi kegiatan mentoring perperiodiknya berdasarkan tahapan dan analisa yang telah dilakukan pada proses RBM. Rekomendasi dari hasil evaluasi juga akan ditampilkan dalam prototipe sistem ini. Software ini dalam pembangunannya akan menggunakan konsep Unified Modelling Language (Pressman, 2001). Analisis dan perancangan dilakukan dengan mengggunakan use Case Diagram, Activity Diagram serta, database menggunakan MySQL dan bahasa pemograman yang digunakan adalah PHP. Perangkat Keras standar yang digunakan dalam pembangunan prototipe ini adalah Processor Celeron, Memory 4 GB, Harddisk berkapasitas 500 GB, Monitor dan Keyboard.

\subsection{Pengujian Prototipe}

Pengujian sistem dilakukan dengan 2 cara, yaitu pengujian Black Box dan User Accaptance Test (UAT). Pada pengujian Black Box, serangkaian kondisi input dan output dalam sistem dengan berbagai persyaratan fungsional program akan diuji. Pengujian UAT dilakukan dengan melakukan survey kecil berkaitan dengan penggunaan sistem. Software ini akan digunakan oleh pementor, pembimbing/pengelola dan level pimpinan.

\section{Hasil dan Pembahasan}

\subsection{Analisa Statistika CFA}

Pertanyaan yang diajukan merujuk kepada Tabel RBM, mulai dari Tabel Keterhubungan Strategi dan Proyek, Penilaian Masalah dan Kesempatan, Analisis Stakeholder, Monitoring terhadap Logical Framework, Arsip Aktivitas, Manajemen Proyek dan
Laporan, Analisa Perbandingan dan Penilaian Proyek. Berdasarkan hasil wawancara tersebut dilengkapi dengan referensi dari berbagai buku dan jurnal beberapa kesimpulan diperoleh dan indikator atau konstrak dirumuskan. Indikator dan konstrak yang diperoleh dipergunakan untuk mengukur performansi pelaksanaan kegiatan mentoring dasar keislaman baik dari segi peserta maupun pementor.

Analisa statistika dengan aplikasi CFA dijalankan pada 80 data responden. Beberapa fungsi yang dilakukan pada analisis CFA diantaranya adalah:

a. Menguji dan memeriksa tingkat kepentingan dari masing-masing indikator yang diajukan serta bagaimana korelasi atau hubungan dari masing-masing indikator dalam membangun konstrak.

b. Menguji dan memeriksa tingkat kepentingan dari masing-masing kontrak serta bagaimana korelasi atau hubungan dari masing-masing konstrak tersebut dalam membangun framework (Model).

Berdasarkan hasil analisa CFA yang telah berhasil dilakukan, model yang digunakan untuk mengukur performansi pelaksanaan kegiatan mentoring dasar keislaman memiliki 7 konstrak dan 32 indikator. Konstrak inilah yang digunakan sebagai tolak ukur keberhasilan pelaksanaan kegiatan mentoring keislaman dengan berbasiskan konsep RBM.

\subsection{Analisa Statistika Deskriptif}

Analisa statistika deskriptif dilakukan untuk mencari nilai performansi dari peserta dengan beberapa klasifikasi sebagai berikut:

a. Performansi seluruh peserta di Fakultas Sains dan Teknologi yang terdiri 500 peserta.

b. Performansi peserta berdasarkan klasifikasi penjurusan, terdiri dari jurusan Teknik Informatika 110 responden, Sistem Informasi 105 responden, Teknik Industri 100 responden, Teknik Elektro 95 responden, Matematika Terapan 90 responden.

c. Performansi peserta yang diklasifikasikan berdasarkan jenis kelamin untuk masing-masing jurusan. Kelompok mentoring laki-laki dan perempuan

d. Performansi peserta yang diklasifikasikan berdasarkan kelompok pembimbing dan pementor.

\subsubsection{Klasifikasi Performansi Fakultas}

Dari 500 responden di Fakultas Sains dan Teknologi UIN SUSKA Riau, diperoleh performansi peserta mentoring dasar keislaman berada pada level menengah(middle) dengan presentase $58.7 \%$.

Pada Gambar 5 dapat diketahui bahwa performansi peserta berada pada level yang tinggi (High) terjadi pada indikator akidah5 (Meyakini semua janji Allah akan semua ketentuan kehidupan 
di dunia dan akhirat (kematian; dosa yang diampuni dengan taubat nasuha; malaikat yang senantiasa mencatat perbuatan manusia; adanya kiamat dan hari pembalasan, meraih indahnya iman dan ibadah)), level menengah berada pada indikator ilmu dan wawasan keislaman 1 (Penguasaan ilmu yang berkaitan dengan nilai-nilai keislaman melalui Alquran dan sunnatullah). Sementara itu level rendah berada pada indikator akidah2 (Menyekutukan Allah swt dalam Asma'-Nya, sifat-Nya dan Af'al-Nya).

\section{Persentase Fakultas}

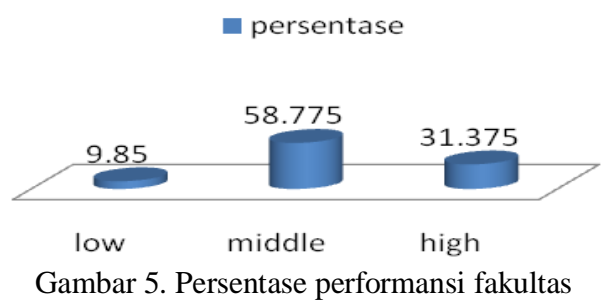

\subsubsection{Klasifikasi Performansi berdasarkan Jurusan}

Terdapat 5 jurusan pada Fakultas Sains dan Teknologi, yaitu jurusan teknik informatika, sistem informasi, teknik industri, teknik elektro dan matematika terapan. Performansi masing-masing jurusan dapat dilihat pada Gambar 6. Berikut penjabaran hasil dari masing-masing jurusan tersebut.

a. Jurusan Teknik Informatika (TIF)

Dari 110 responden Teknik Informatika didapatkan performansi peserta berada pada level yang tinggi (High) terlihat pada indikator akidah5 (Meyakini semua janji Allah akan semua ketentuan kehidupan di dunia dan akhirat (kematian; dosa yang diampuni dengan taubat nasuha; malaikat yang senantiasa mencatat perbuatan manusia; adanya kiamat dan hari pembalasan, meraih indahnya iman dan ibadah)), level Menengah berada pada indikator IWK2 (Penguasaan ilmu yang berkaitan dengan fenomena alam dan kehidupan yang dikaitkan dengan pemahaman Al-Quran dan sunnatullah), level rendah (low) berada pada indicator akidah2 (menyekutukan Allah swt dalam Asma'-Nya, sifatNya dan Af'al-Nya).

\section{b. Jurusan Sistem Informasi (SI)}

Dari 105 responden Sistem Informasi didapatkan Performansi peserta berada pada level yang tinggi (High) terlihat pada indikator akidah5 (Meyakini semua janji Allah akan semua ketentuan kehidupan di dunia dan akhirat (kematian; dosa yang diampuni dengan taubat nasuha; malaikat yang senantiasa mencatat perbuatan manusia; adanya kiamat dan hari pembalasan, meraih indahnya iman dan ibadah)), level Menengah berada pada indikator IWK2 (Penguasaan ilmu yang berkaitan dengan fenomena alam dan kehidupan yang dikaitkan dengan pemahaman Al-Quran dan sunnatullah), level rendah (low) berada pada indikator akidah2 (menyekutukan Allah swt dalam Asma'-Nya, sifat-Nya dan Af'alNya).

\section{c. Jurusan Teknik Industri (TIN)}

Dari 100 responden Teknik Industri didapatkan Performansi peserta berada pada level yang tinggi (High) terlihat pada indikator akidah5 (Meyakini semua janji Allah akan semua ketentuan kehidupan di dunia dan akhirat (kematian; dosa yang diampuni dengan taubat nasuha; malaikat yang senantiasa mencatat perbuatan manusia; adanya kiamat dan hari pembalasan, meraih indahnya iman dan ibadah)), level Menengah berada pada indikator IWK1 (Penguasaan ilmu yang berkaitan dengan nilai-nilai keislaman melalui Al-quran dan sunnatullah), level rendah (low) berada pada indikator akidah2 (menyekutukan Allah swt dalam Asma'-Nya, sifatNya dan Af'al-Nya).

\section{d. Jurusan Teknik Elektro (TE)}

Dari 95 responden Teknik Elektro didapatkan Performansi peserta berada pada level yang tinggi (High) terlihat pada indikator akidah5 (Meyakini semua janji Allah akan semua ketentuan kehidupan di dunia dan akhirat (kematian; dosa yang diampuni dengan taubat nasuha; malaikat yang senantiasa mencatat perbuatan manusia; adanya kiamat dan hari pembalasan, meraih indahnya iman dan ibadah)), level Menengah berada pada indicator IWK3 (Penguasaan terhadap buku-buku akidah, tafsir juz 30, hukum dan hafalan tajwid juz 30),level rendah (low) berada pada indikator akidah2 (menyekutukan Allah swtdalamAsma'-Nya, sifat-Nya dan Af'al-Nya). e. Jurusan Matematika Terapan (MATER)

Dari 90 responden Matematika Terapan didapatkan Performansi peserta berada pada level yang tinggi (High) terlihat pada indikator Ibadah5 (Kebiasaan membaca Al-quran baik dalam bentuk Tahfiz maupun Tahsin), level Menengah berada pada indikator Akhlaq3 (Menjauhi sifat hasad dan dengki terhadap orang lain), level rendah (low) berada pada indicator akidah2 (menyekutukan Allah swt dalam Asma'-Nya, sifat-Nya dan Af'al-Nya).

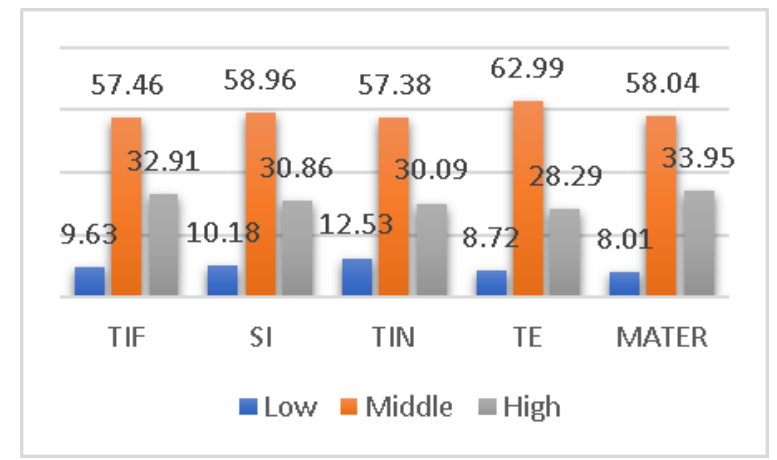

Gambar 6. Persentase performansi berdasarkan jurusan 


\subsection{Rancangan Pembangunan Sistem Informasi Manajemen}

Permasalahan yang terjadi pada sistem lama dapat diperbaiki dengan membangun sebuah sistem manajemen yang bertujuan untuk memonitor dan mengevaluasi proses kegiatan ini. Secara umum, sistem ini mampu memberikan informasi secara lengkap tentang aktivitas kegiatan mentoring, melakukan pengolahan data secara realtime, melakukan proses entri data nilai, pengisian kuisioner, diskusi online, berbagi informasi dalam bentuk pengumuman ataupun pelaporan dan berbagai fitur lainnya.

\subsubsection{Pengguna Sistem}

Sesuai dengan stakeholder yang terlibat dalam aktivitas kegiatan mentoring ini, pengguna yang dapat berinteraksi adalah administrator, pimpinan, peserta, pembimbing dan pementor. Administrator memiliki kendali penuh terhadap sistem, seperti melakukan manajemen pengguna, manajemen kuisioner, manajemen peserta, manajemen pementor, mengelola performansi sebagai hasil evaluasi dan proses monitoring dan lain sebagainya. Pimpinan memiliki akses untuk dapat berinteraksi dengan pengguna lainya misalnya berdiskusi secara realtime dengan pementor, pembimbing dan pengelola, dapat melihat hasil evaluasi dan monitoring; melihat performansi dari masing-masing peserta dan pementor, memperoleh rekomendasi sebagai masukan perbaikan untuk kegiatan mentoring selanjutnya; melihat permasalahan yang dihadapi selama kegiatan mentoring berlangsung, dan sebagainya. Pementor memiliki hak akses untuk memasukkan hasil evaluasi dan penilaian yang dilakukan kepada peserta; memberikan informasi dan tugas-tugas yang diperlukan kepada peserta; melakukan diskusi dan komunikasi yang baik kepada peserta, sesama pementor maupun pembimbing. Pembimbing dan Pengelola.

Pembimbing dan pengelola memiliki hak akses untuk mengevaluasi peserta; memberikan penilain kinerja pementor; melihat performansi peserta baik secara individu, kelompok maupun seluruhnya; menentukan kelulusan peserta; melakukan diskusi dengan sesama pembimbing/pengelola, diskusi dengan pimpinan, pementor dan peserta.

Use case diagram untuk pimpinan dapat dilihat pada Gambar 7. Activity Diagram untuk menu forum diskusi dapat dilihat pada Gambar 8. Sementara interface untuk pengelolaan kuesioner dapat dilihat pada Gambar 9.

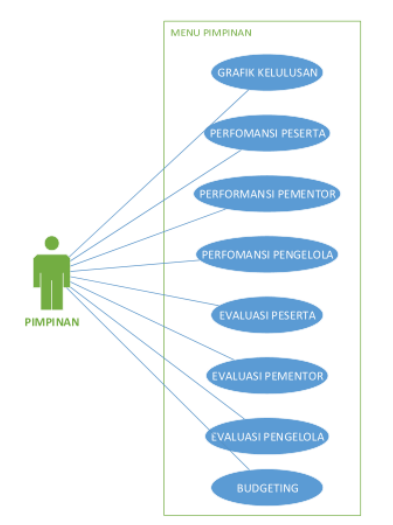

Gambar 7. Use Case Pimpinan

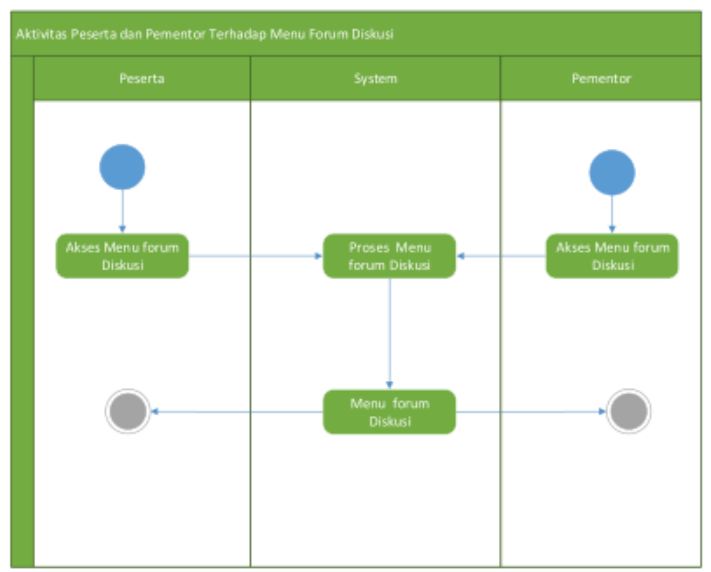

Gambar 8. Activity Diagram menu forum diskusi

\subsection{Pembahasan}

Dari hasil analisis statistika yang dilakukan terhadap 500 orang responden diperoleh performansi capaian kesuksesan kegiatan mentoring ini berada pada level menengah dengan presentase $58.7 \%$. Dari analisis tersebut diperoleh bahwa kondisi Fakultas memiliki keberhasilan yang tinggi dibidang pelaksanaan dan pemantapan akidah5 yaitu meyakini semua janji Allah akan semua ketentuan kehidupan di dunia dan akhirat (kematian; dosa yang diampuni dengan taubat nasuha; malaikat yang senantiasa mencatat perbuatan manusia; adanya kiamat dan hari pembalasan, meraih indahnya iman dan ibadah)). Kepercayaan tersebut dituangkan dalam berbagai kegiatan dalam kehidupan sehari-hari misalnya dengan menyemarakkan nuansa islamiah dilingkungan Fakultas melalui berbagai kegiatan seperti ceramah agama dan keislaman, latihan sholat jenazah, sholat fardhu dan sholat sunnah, memperbaiki bacaan Alquran, kegiatan hafiz Quran (juz 30). 


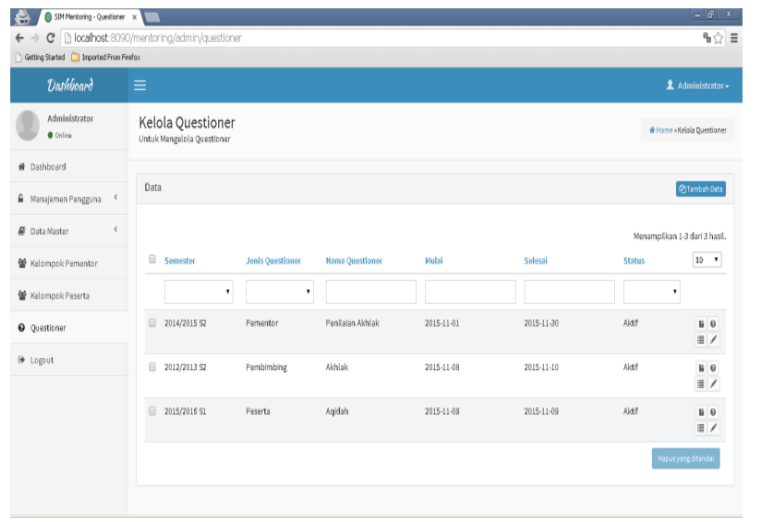

Gambar 9. Interface Prototype kelola kuesioner

Proses monitoring dan evaluasi ini tidak hanya dapat dilakukan oleh pimpinan saja, namun seluruh stakeholders yang terlibat dalam kegiatan ini. Sementara level terendah berada pada indikator akidah2 yaitu Menyekutukan Allah swt dalam Asma'$N y a$, sifat-Nya dan $A f^{\prime} a l-N y a$. Hal ini menunjukkan bahwa peserta mentoring sudah begitu mengerti bahwa tidak dibenarkan untuk mensekutukan Allah dengan sesuatu apapun bahkan aktivitas harian yang mengarah kepada perbuatan yang mempersekutukan Allah dihindari seperti permainan kartu magic, hipnotis, dan kegiatan lainnya.

Selain performansi pencapaian pelaksanaan kegiatan mentoring ini seluruh aktivitas harian dalam pelaksanaan terarsip dengan baik melalui MIS ini. Rekapitulasi absensi, nilai harian, nilai UTS dan UAS, nilai ujian praktek terorganisir dengan baik dan transparan. Komunikasi antara pementor, peserta, pengelola bahkan pembimbing terjalin dengan sangat komunikatif, sehingga informasi diantara komponen stakeholder tersebut tidak terputus dan bisa dilakukan kapan saja dan dimana saja.

Dari hasil interview dan studi literatur, terdapat 35 indikator dari 7 buah konstrak yang menjadi key success factor. Keseluruhan indikator dan konstrak inilah yang dijadikan sebagai tolak ukur untuk mengevaluasi dan menilai performansi pencapaian kesuksesan pelaksanaan kegiatan. Akan tetapi, berdasarkan hasil analisis CFA, 3 indikator harus dieliminasi guna meningkatkan nilai faktor loading yaitu indikator akidah1 (Pengkafiran seorang muslim) dan akidah3 (Mempelajari madzhabmadzhab Islam yang berkaitan dengan Asma dan Sifat dan mengikuti madzhab salaf) pada konstrak Akidah, dan indikator KJ3 (Kebiasaan berolahraga secara teratur (10-15 menit) setiap harinya atau 2-3 jam setiap minggunya) pada konstrak Kebugaran Jasmani.

Prototipe rancangan software MIS sebagai aplikasi monitoring dan evaluasi berbasis RBM telah berhasil dilakukan. Sistem ini dibangun dengan spesifikasi hardware dan Software yang telah didefinisikan sesuai dengan standard. Model Object
Oriented dengan aplikasi UML digunakan untuk menggambarkan hasil analisa dan rancangan sistem.

Pengujian blackbox melibatkan sebanyak 5 komponen uji, yaitu halaman login, halaman administrator, halaman pimpinan, halaman pembimbing, halaman pementor dan halaman peserta. Keseluruhan akses untuk masing-masing komponen telah berhasil diuji. Sementara pengujian UAT dilakukan dengan menyebarkan 30 kuesioner terkait penilaian penggunaan sistem yang diberikan kepada pimpinan, pementor, pembimbing, dan peserta. Sebagai hasilnya diperoleh bahwa prototype system ini cukup mudah untuk digunakan (85\%), menarik secara interface $(80 \%)$, dapat membantu transformasi dan transparansi informasi dalam pengelolaan kegiatan (90\%), dapat membantu memonitor dan mengevaluasi pelaksanaan kegiatan (95\%), dan membantu dalam mengambil keputusan untuk perbaikkan $(95 \%)$.

\section{Kesimpulan}

Proses monitoring dan evaluasi dengan menggunakan konsep Result Based Management Information System ini tidak hanya dapat memonitor dan mengevaluasi pelaksanaan kegiatan di Fakultas, namun informasi lebih lengkap untuk setiap jurusan. Performansi dari masing-masing kelompok mentoring hingga performansi individu peserta juga dapat diperoleh. Informasi performansi pementor maupun dosen pendamping juga dapat di monitor dan dievaluasi. Hal ini tentunya akan bermanfaat sebagai rekomendasi dan perbaikkan untuk pelaksanaan kegiatan berikutnya. Penelitian ini juga memberikan prototipe rancangan software management information system sebagai tools dalam memonitoring dan mengevaluasi berbasis RBM.

Data pada penelitian yang diperoleh adalah pada pelaksanaan kegiatan mentoring di tahun 2014. Penelitian selanjutnya dapat menggunakan data sejak kegiatan mentoring ini pertama kali ada di lingkungan UIN SUSKA Riau (2010) hingga sekarang. Sehingga, perubahan pelaksanaan kegiatan terarsip dan termonitor dengan sangat baik dan terstruktur. Setiap permasalahan dalam pelaksanaan kegiatan juga dapat dideteksi dari awal berdasarkan pengalaman permasalahan di tahun sebelumnya. Kemudian, beberapa key success factor yang digunakan dalam menentukan kesuksesan pelaksanaan kegiatan ini bisa dikembangkan kembali sesuai dengan kondisi dan permasalahan yang dihadapi setiap tahunnya. Sehingga bisa bersifat dinamis. Untuk pengembangan sistem RBMIS selanjutnya dapat dirancang dengan menggunakan teknologi Android, sehingga pengaksesan dapat dengan lebih mudah dilakukan. Sistem RBMIS juga dapat dikembangkan kedalam bentuk KMS (Knowledge Management System) agar user dapat 
melakukan sharing pengalaman dan permasalahan selama pelaksanaan kegiatan.

\section{Daftar Pustaka}

Arif, M., Jubair, M., \& Ahsan, A., 2017. Use of Result Based Management (RBM) Framework for Monitoring Projects of Public Sector in Pakistan - A Case Study. International Journal of Innovation, Management and Technology, $6(2)$, 130-135. https://doi.org/10.7763/IJIMT.2015.V6.589

Azmi, M., 2006. Pembinaan Akhlak Anak Usia Pra Sekolah, Upaya Mengefektifkan Nilai-Nilai Pendidikan Islam dalam Keluarga. Belukar, Yogyakarta.

Coakes, S. \& Sheridan, J., 2003. SPSS: Analysis without Anguish: Version 11.0 for Windows. John Wiley \& Sons, Inc, Australia.

Creswell, J.W., 2003. Research Design: Qualitative, Quantitative and Mixed Methods Approach (2nd ed.). SAGE Publication, London.

El-ebiary, Y.A.B., Mahmoud, M., \& Alzubi, S., 2016. The Impact of Management Information System in Educational Organizations Processes. In IEEE Conference on e-Learning, $e$ Management and e-Services (IC3e) The (pp. 166169).

George, C., 2006. 5-point vs. 6-point Likert Scales. SearchWarp Writers Community. Retrieved from http://searchwarp.com/swa69773.htm.

Handbook, 2010. Result Based Management Handbook: Strengthening RBM harmonization for improved development results. United Nation Development Group.

Irham, M., 2012. Etos Kerja dalam Perspektif Islam. Jurnal Subtantia, 14(1, April).

Johnston, J., Tomlinson, H. \& Susan, H., 2007. The Assessment: Developmental Child Case Study. Developmental Child Case Study: Example Assessment, Rubrics, and Data Tables for NAEYC.

Kusek, J.Z. \& Rist, R.C., 2004. Ten Steps to a Result Based Monitoring and Evaluation System. The World Bank, Washington, D.C.

MacKenzie, A. 2008. Result Based Management at Country Level: Systemic Issues that Prevent Good UNDAF results and the use of UNDAF result information. In Paper presented to the United Nations Development Group s Working Group on Programming Policy. United nation.

Matthew, B. \& Micheal, A., 1994. Qualitative Data Analysis 2 nd edn. : SAGE Publication, London, UK.

Mayne, J., 2007. Best Practices in Results Based Management: AReview of Experiences - A Report for the United Nations Secretariat, 1 .
Mckernan, E., Kennedy, K. \& Aldred, A., 2016. Adopting results based management in the nonprofit sector: Trócaire' $\mathrm{s}$ experience. Project Management Research and Practice, 3(July-Dec). https://doi.org/10.5130/pmrp.v3i0.5122

Meier, W., 2003. Results Based Management: Towards a common understanding among development cooperation agencies. In Prepared for the Canadian International Development Agency, Performance Review Brach,for consideration by the DAC Working Party on Aid Effectiveness and Harmonitation, Oktober.

Mutohir, T.C. \& Maksum, A., 2007. Sport Development Index. PT.Indeks, Jakarta.

Okfalisa, Dayub., 2015. Aplikasi Knowledge Management Metrics pada Perancangan Dashboard KMS untuk Monitoring Strategi (Studi Kasus : Fakultas Sains dan Teknologi UIN Suska Riau). Seminar Nasional Teknologi Informasi, Komunikasi dan Industri (SNTIKI)7. Pekanbaru, 11 November 2015. 148-156.

Ortiz, F., Kuyama, E., Munch, S., \& Tang, W.G., 2004. Implementation of Result Based Management in United Nations Organization Part 1 - Series on Managing for Results in the United Nations System. Joint Inspection Unit, Geneva.

Pressman, R.R., 2001. Software Engineering A Practitioners' Approach. Mc.GrawHills, New York.

Saide, Trialih, R., Wei, H., Okfalisa, \& Anugrah, W., 2017. Knowledge Sharing Behaviour and Quality Among Workers of Academic Institution in Indonesia. International Journal of Business and Society, 18(2), 353-368.

Sirait, B.C., 2008. The Power of Public Speaking: Kiat Sukses Berbicara di depan Publik. Gramedia Pustaka Utama, Jakarta.

Solechan, A. \& Prasandy, T., 2016. Rancang Bangun Tata Kelola Kinerja Perguruan Tinggi Menggunakan IT Balanced Scorecard. Jurnal Sistem Informasi Bisnis, 1, 84-89. https://doi.org/10.21456/vol6iss1pp84-89

Speckley, F., 2009. Result Based Monitoring and Evaluation Toolkit (2nd ed.). Local Livelihoods.

Stemler, S., 2001. An Overview of Content Analysis. Practical Assessment, Research \& Evaluation, 7(17), 1-8.

United Nation Development Group, 2011. Result Based Management Handbook: Harmonizing RBM Concept and approaches for Improved Development Result at Country Level.

Zuhairini, 2000. Ilmu Pendidikan Islam. Bumi Aksara, Jakarta. 